\title{
Relationship between Senior Drivers' Cognitive and Physical Functions and Urban Driving Behaviors during Behind-the-Wheel Driving Education Sessions with Driving Instructors
}

\author{
Takashi Yonekawa, Takahiro Tanaka, Hirofumi Aoki, Misako Yamagishi, Yuki Yoshihara, \\ Eijiro Takeuchi, Issey Takahashi, Yoshiki Ninomiya, Hitoshi Kanamori, Tatsuya Suzuki, \\ Makoto Inagami \\ Institute of Innovation for Future Society, Nagoya University, Nagoya, Japan \\ Email: yonekawa@coi.nagoya-u.ac.jp, tanaka@coi.nagoya-u.ac.jp, hiro.aoki@nagoya-u.jp, yamagishi@coi.nagoya-u.ac.jp, \\ y-yuki@coi.nagoya-u.ac.jp, takeuchi@coi.nagoya-u.ac.jp, takahashi@coi.nagoya-u.ac.jp,ninomiya@coi.nagoya-u.ac.jp, \\ hitoshi_kanamori@coi.nagoya-u.ac.jp,t_suzuki@nuem.nagoya-u.ac.jp, inagami@coi.nagoya-u.ac.jp
}

How to cite this paper: Yonekawa, T., Tanaka, T., Aoki, H., Yamagishi, M., Yoshihara, Y., Takeuchi, E., Takahashi, I., Ninomiya, Y., Kanamori, H., Suzuki, T. and Inagami, M. (2017) Relationship between Senior Drivers' Cognitive and Physical Functions and Urban Driving Behaviors during Behind-the-Wheel Driving Education Sessions with Driving Instructors. Journal of Transportation Technologies, 7, 148-166. https://doi.org/10.4236/jtts.2017.72011

Received: December 23, 2016

Accepted: April 15, 2017

Published: April 18, 2017

Copyright $\odot 2017$ by authors and Scientific Research Publishing Inc. This work is licensed under the Creative Commons Attribution International License (CC BY 4.0).

http://creativecommons.org/licenses/by/4.0/

\begin{abstract}
Recently, traffic accidents caused by elderly drivers have been increasing. It is thought that the reasons of accidents are functions such as decline of eyesight, cognition and physical strength caused by aging. In order to assist safe driving for elderly drivers, it is necessary to sufficiently understand any possible relationship of various senior drivers' cognition, physical strength and driving behavior. In this paper relationship of elderly driver's cognition, physical strength and driving behaviors were analyzed using the result of driving instructions on urban road by driving school instructors.
\end{abstract}

\section{Keywords}

Human Engineering, Elderly Person, Driver Characteristics, Driving Instruction

\section{Introduction}

In Japan, the growing elderly population has led to an increased proportion of elderly drivers; accordingly, the number of traffic accidents caused by elderly drivers is also increasing [1]. To address this matter, this study was conducted as part of the Nagoya Center of Innovation (COI) program promoted by the Ministry of education, culture, sports, science and technology and the Japan Science and Technology Agency (JST) in an attempt to safely delay the cessation of 
driving for the average elderly driver [2].

Delaying the cessation of driving requires driver education and the development of support systems for the elderly that consider the relationship between aspects of driving, such as decision-making and physical control while driving, and human characteristics such as physical attributes and cognitive function [3]. According to data on traffic accidents, the second most frequent collision type, after rear-end collisions, is bumping at intersections (crossing collisions), and the data show that seniors, in particular, are often involved in crossing collisions [4]. Additionally, elderly drivers have been shown to exhibit delayed response during emergencies at intersections [5] and insufficiently check both sides at stop sign intersections [6]. In order to understand these challenges, our experiment provided behind-the-wheel training to elderly drivers on city streets that included intersections with stop signs, where it is easy for crossing collisions to occur. This behind-the-wheel training was given by a driving instructor from a driving school who was present in the car with each elderly driver [7]. In our previous report, the content of the instructions given by the driving instructors was analyzed and a proposal was made for a system to assist with driving instructions for the elderly [8]. This report investigates the relationship between the frequencies of instructions given to senior drivers at stop sign intersections and driving behaviors, physical strength, and cognitive function; it also discusses a proposed method for supporting safe driving by the elderly.

\section{Experimentation Methods}

\subsection{Subjects}

The subjects consisted of a total of 24 elderly people (Id $1 \sim \operatorname{Id} 24)$ comprising 12 males and 12 females. One of four driving instructors (Is1 Is4) rode with each subject and provided instructions from the passenger seat. Table 1 shows the combinations of subjects and driving instructors and the conditions under which the session was conducted.

\subsection{Measurement Methods}

The elderly drivers were asked to follow the circular driving route shown in Figure 1. This course (intersections $5 \rightarrow 6 \rightarrow 9 \rightarrow 1 \rightarrow 4 \rightarrow 5$ ) is located on residential streets near Nagoya University, and the elderly drivers completed it in 17 to 30 minutes. This circular course included 10 intersections: three were stop sign intersections where a left turn was made, two were stop sign intersections where the driver proceeded straight, one was an intersection with a convex mirror where a left turn was made without stopping, and four were intersections where the driver proceeded straight without stopping (one of these had a flashing yellow signal). Many of these stop sign intersections had poor visibility, and there were two places where the route passed over a pedestrian crossing: one intersection where a left turn was made without stopping and one intersection where the driver proceeded straight without stopping. Half of the driving route was on 
Table 1. Details of driving instructors and subjects.

\begin{tabular}{|c|c|c|c|c|c|c|c|}
\hline Is & $\begin{array}{l}\text { Is: Age } \\
\text { (Instruct } \\
\text { years) }\end{array}$ & Id: No & Id: Age & Gender & Start time & $\begin{array}{c}\text { Lesson } \\
\text { duration }\end{array}$ & Weather \\
\hline \multirow{8}{*}{ Is 1} & \multirow{8}{*}{$42(18)$} & 1 & 57 & Female & 9:29:39 & $0: 22: 49$ & Fine \\
\hline & & 2 & 54 & Female & $10: 37: 30$ & $0: 24: 01$ & Fine \\
\hline & & 3 & 74 & Female & $10: 34: 03$ & $0: 24: 54$ & Cloudy \\
\hline & & 4 & 75 & Female & $9: 28: 57$ & $0: 17: 36$ & Cloudy \\
\hline & & 5 & 75 & Male & $9: 30: 35$ & $0: 22: 48$ & Rain \\
\hline & & 6 & 70 & Male & $10: 32: 48$ & 0:23:08 & Rain \\
\hline & & 7 & 70 & Male & $9: 24: 08$ & $0: 24: 32$ & Fine/snow \\
\hline & & 8 & 77 & Male & $10: 33: 49$ & $0: 20: 49$ & Fine/snow \\
\hline \multirow{6}{*}{ Is 2} & \multirow{6}{*}{46 (19) } & 9 & 67 & Female & $14: 07: 33$ & 0:17:08 & Fine \\
\hline & & 10 & 76 & Female & $15: 07: 27$ & $0: 19: 51$ & Fine \\
\hline & & 11 & 70 & Male & $13: 58: 59$ & $0: 32: 47$ & Cloudy \\
\hline & & 12 & 68 & Female & $15: 16: 30$ & $0: 31: 54$ & Cloudy \\
\hline & & 13 & 54 & Female & $13: 55: 36$ & 0:28:09 & Rain \\
\hline & & 14 & 65 & Female & $15: 05: 33$ & $0: 26: 34$ & Rain \\
\hline \multirow{4}{*}{ Is 3} & \multirow{4}{*}{$48(23)$} & 15 & 66 & Male & 9:19:19 & $0: 23: 18$ & Fine \\
\hline & & 16 & 59 & Male & 10:29:00 & $0: 21: 58$ & Fine \\
\hline & & 17 & 68 & Male & $9: 15: 40$ & $0: 22: 50$ & Fine \\
\hline & & 18 & 64 & Female & $10: 25: 28$ & $0: 24: 49$ & Fine \\
\hline \multirow{6}{*}{ Is 4} & \multirow{6}{*}{44 (18) } & 19 & 79 & Female & $14: 13: 47$ & $0: 20: 05$ & Fine/snow \\
\hline & & 20 & 73 & Female & $15: 16: 18$ & $0: 27: 31$ & Fine/snow \\
\hline & & 21 & 52 & Male & 14:01:42 & 0:30:01 & Fine \\
\hline & & 22 & 77 & Male & 15:11:44 & $0: 29: 52$ & Fine \\
\hline & & 23 & 50 & Male & $13: 45: 07$ & $0: 32: 51$ & Fine \\
\hline & & 24 & 55 & Male & $14: 55: 44$ & $0: 27: 27$ & Fine \\
\hline
\end{tabular}

one-way roads. The roads on the course, including both one-way roads and twoway roads without center lines, were narrow enough to require driving slowly and intentionally making room to avoid cars in the opposite lane, parked cars, pedestrians, and bicycles.

As the subjects were not driving their own vehicles, they were given time to practice driving the vehicle provided while the driving instructors accompanied them in the passenger seat. After they had mastered the vehicle and the driving instructor had given them instructions on driving, including navigation and the operation of the auxiliary brake, they began their experimental drive on the public roads [7]. Prior to this, cognitive function tests such as the Mini-Mental State Examination (MMSE), Trail-Making Test (TMT) Parts A \& B, and Useful Field of View (UFOV) test [a visual information processing speed task from the Driving Health Inventory (DHI)] had been conducted on all subjects. In addition, the subjects' suitability for driving was examined using the National Police Agency's Driving Aptitude Testing Device (Takei Scientific Instruments Co., Ltd.). The relationship between these test results and the frequency of instructions that the instructors provided to each driver while on the road was investigated [2]. Driv- 
ing data was recorded with a BU-DRHD421 driving recorder (Yupiteru) that was equipped with a GPS (Global Positioning System) system and an acceleration sensor. Footage from a camera facing out from the front of the vehicle and that from a camera aimed at the driver were continuously recorded. Figure 2 shows an example of the recorded data.

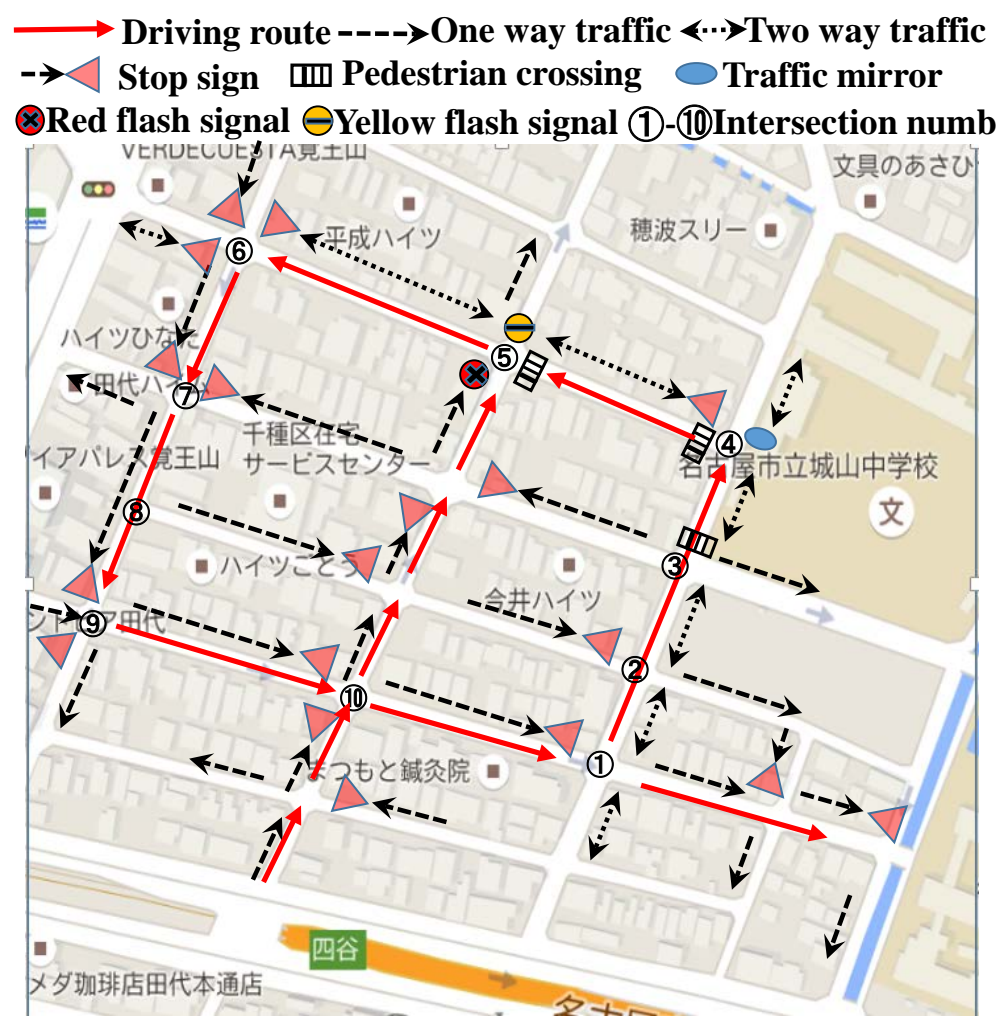

Figure 1. Driving route of experiment.

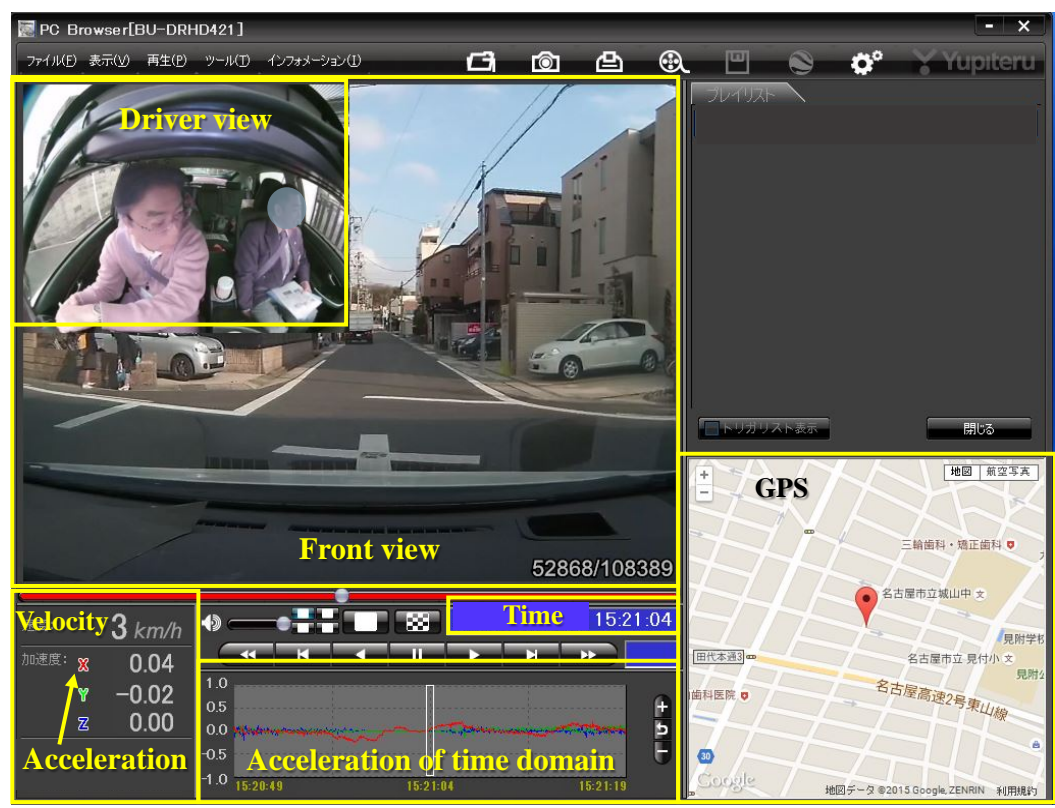

Figure 2. Example of driving-recorder viewer. 
After they were provided with an explanation of the content of the experiment, informed consent was obtained from all subjects and instructors before the experiment. This experiment passed an ethical review performed by Nagoya University's Institute of Innovation for Future Society.

\subsection{Analytical Method}

After each experimental drive, the content of the instructions given by the instructors was written down from the recording voice of driving-recorder (Figure 2 ) and analyzed as follows. On the basis of the situation in which each instruction was given, including the location and driving behavior, the timing of each instruction was classified into one of the following five categories: in advance, immediately before, during a maneuver, immediately after, or as a review. The intention of each instruction was then sorted into one of the following five categories on the basis of its content: information, warning, instruction, navigation, and non-instruction for passing through an intersection. The content of each driving instruction was classified into one of the following eight categories: completely stop; stop before the stop line; brake; check left and right; go slowly; keep left; start moving; and (how to) navigate. The frequency of advice in each content category was calculated. Table 2 shows examples of the content of the driving instructions that were extracted from the drive recorder.

Furthermore, the time at which each braking maneuver started (Tbs) and ended (Tbe) was identified from the vehicle acceleration data as time data points, as shown in Figure 3. Data from the front-view camera (Figure 4) was used to identify the moment at which the vehicle's hood touched the center mark of an intersection as the time of intersection entry (Tie ).The speed calculated by GPS signal was used, and the acceleration was used the value of the acceleration sensor of the drive recorder. Because the speed by GPS signal had a time lag of one second or more at the sampling frequency (about $1 \mathrm{~Hz}$ ) of the GPS signal, the acceleration did not coincide with the gradient of the speed-time graph in Figure 3. However, the speed was not calculated by the integrated value of acceleration, because the acceleration sensor signal included the drift of the signal and the road slope error. Therefore, the average acceleration and the deceleration distance are calculated by the speed change per time. Table 3 shows example of driving behavior calculations of the Figure 3 graph.

The velocity at the start of braking ( $V b s$ ) and that at the end of braking ( $V b s$ ) were calculated using speed. In addition, the following braking information was calculated: the maximum deceleration for a single application of the brake ( $G$ max ), time of continuous braking ( $T b=T b e-T b s$ ), average deceleration for a single application of the brake ( Gave $=(V b s-V b e) \div T b$ ), constant acceleration ratio of the maximum deceleration to the average deceleration as an indicator of the smoothness of braking ( $R g=G \max /$ Gave ), braking distance required for deceleration $(D b=T b \times(V b s-V b e) \div 2)$, and time margin for starting to brake ( $T m b=D b \div V b s)$. The time spent checking left and right was calculated as the interval between the completion of braking and the time of intersection entrance 
Table 2. Example of driving instruction analysis.

\begin{tabular}{|c|c|c|c|c|c|c|c|c|c|c|c|}
\hline No & $\begin{array}{l}\text { Map } \\
\text { No }\end{array}$ & $\begin{array}{l}\text { Road } \\
\text { situation }\end{array}$ & Driving & Time & $\begin{array}{l}\text { Driving } \\
\text { instruction } \\
\text { comment }\end{array}$ & \multicolumn{2}{|c|}{$\begin{array}{l}\text { Instruction } \\
\text { intention }\end{array}$} & Timing & \multicolumn{3}{|c|}{ Driving instruction } \\
\hline 1 & $10 \rightarrow 11$ & $\begin{array}{c}\text { One-way } \\
\text { traffic }\end{array}$ & $\begin{array}{l}\text { Straight } \\
\text { ahead way }\end{array}$ & $9: 29: 20$ & $\begin{array}{l}\text { We'll turn left at that } \\
\text { red flashing signal. }\end{array}$ & Navigation & & In advance & Navigating & & \\
\hline 2 & 11 & $\begin{array}{l}\text { One-way } \\
\text { intersection }\end{array}$ & $\begin{array}{c}\text { Straight } \\
\text { ahead } \\
\text { intersection }\end{array}$ & $9: 29: 24$ & $\begin{array}{l}\text { It's slow. I have a bad } \\
\text { perspective. Slow } \\
\text { down. }\end{array}$ & Instruction & & $\begin{array}{l}\text { Immediately } \\
\text { before }\end{array}$ & Slowing down & & \\
\hline 3 & 11 & $\begin{array}{l}\text { One-way } \\
\text { intersection }\end{array}$ & $\begin{array}{l}\text { Straight } \\
\text { ahead } \\
\text { intersection }\end{array}$ & $9: 29: 28$ & $\begin{array}{l}\text { How to accelerate } \\
\text { slowly. }\end{array}$ & Instruction & & $\begin{array}{l}\text { Immediately } \\
\text { after }\end{array}$ & $\begin{array}{c}\text { Mild } \\
\text { accelerating }\end{array}$ & & \\
\hline 4 & 12 & $\begin{array}{l}\text { One-way } \\
\text { stop sign } \\
\text { intersection }\end{array}$ & $\begin{array}{l}\text { Straight } \\
\text { ahead stop } \\
\text { sign }\end{array}$ & $9: 29: 31$ & $\begin{array}{l}\text { Stop it. Stop so as not } \\
\text { to cross the stop line. } \\
\text { Yes, brake, brake, } \\
\text { and firmly brake. }\end{array}$ & Caution & Instruction & $\begin{array}{l}\text { Immediately } \\
\text { before }\end{array}$ & Braking & Stopping & $\begin{array}{l}\text { Stopping } \\
\text { position }\end{array}$ \\
\hline 5 & 12 & $\begin{array}{l}\text { One-way } \\
\text { stop sign } \\
\text { intersection }\end{array}$ & $\begin{array}{l}\text { Straight } \\
\text { ahead stop } \\
\text { sign }\end{array}$ & 9:29:39 & $\begin{array}{l}\text { Also, checking while } \\
\text { looking at it. }\end{array}$ & Instruction & & $\begin{array}{l}\text { During } \\
\text { maneuver }\end{array}$ & $\begin{array}{l}\text { Left and right } \\
\text { checking }\end{array}$ & & \\
\hline 6 & $12 \rightarrow 5$ & $\begin{array}{l}\text { One-way } \\
\text { traffic }\end{array}$ & $\begin{array}{l}\text { Straight } \\
\text { ahead way }\end{array}$ & 9:29:43 & $\begin{array}{c}\text { I will make a left turn } \\
\text { on that stop. Turn } \\
\text { left here. }\end{array}$ & Navigation & & $\begin{array}{l}\text { Immediately } \\
\text { before }\end{array}$ & Navigating & & \\
\hline 7 & 5 & $\begin{array}{l}\text { One-way } \\
\text { red flashing } \\
\text { signal } \\
\text { intersection }\end{array}$ & $\begin{array}{l}\text { Left turn } \\
\text { stop sign }\end{array}$ & 9:29:46 & $\begin{array}{l}\text { Firm brake. Such } \\
\text { crossing car may } \\
\text { come. }\end{array}$ & Instruction & Caution & $\begin{array}{l}\text { Immediately } \\
\text { before }\end{array}$ & Braking & & \\
\hline 8 & 5 & $\begin{array}{l}\text { One-way } \\
\text { red flashing } \\
\quad \text { signal } \\
\text { intersection }\end{array}$ & $\begin{array}{l}\text { Left turn } \\
\text { stop sign }\end{array}$ & 9:29:53 & $\begin{array}{l}\text { So red flashing signal } \\
\text { is stop. It is same } \\
\text { meaning as a stop } \\
\text { sign. }\end{array}$ & Information & Caution & $\begin{array}{l}\text { Immediately } \\
\text { before }\end{array}$ & Stopping & & \\
\hline 9 & 5 & $\begin{array}{l}\text { One-way } \\
\text { red flashing } \\
\text { signal } \\
\text { intersection }\end{array}$ & $\begin{array}{l}\text { Left turn } \\
\text { stop sign }\end{array}$ & $9: 29: 58$ & $\begin{array}{l}\text { Okay, we go ahead } \\
\text { little by little. While } \\
\text { turning steering } \\
\text { wheel. Let's apply } \\
\text { brake more. }\end{array}$ & Instruction & Instruction & $\begin{array}{l}\text { During } \\
\text { maneuver }\end{array}$ & $\begin{array}{l}\text { Left and right } \\
\text { checking }\end{array}$ & $\begin{array}{l}\text { Slowing } \\
\text { down }\end{array}$ & Steering \\
\hline 10 & 5 & $\begin{array}{l}\text { One-way } \\
\text { red flashing } \\
\text { signal } \\
\text { intersection }\end{array}$ & $\begin{array}{l}\text { Left turn } \\
\text { stop sign }\end{array}$ & 9:30:04 & $\begin{array}{l}\text { Because it is narrow, } \\
\text { return steering } \\
\text { wheel. }\end{array}$ & Instruction & & $\begin{array}{l}\text { During } \\
\text { maneuver }\end{array}$ & Steering & & \\
\hline 11 & $5 \rightarrow 6$ & $\begin{array}{l}\text { Two-way } \\
\text { traffic both } \\
\text { side parked } \\
\text { vehicles and } \\
\text { a pedestrian }\end{array}$ & $\begin{array}{c}\text { Avoid } \\
\text { parked } \\
\text { vehicles and } \\
\text { a pedestrian }\end{array}$ & 9:30:09 & $\begin{array}{c}\text { Let's keep on } \\
\text { braking. It's narrow. } \\
\text { Brake, brake. More } \\
\text { brakes, more brakes. }\end{array}$ & Instruction & Instruction & $\begin{array}{l}\text { During ma- } \\
\text { neuver }\end{array}$ & Braking & $\begin{array}{l}\text { Slowing } \\
\text { down }\end{array}$ & \\
\hline
\end{tabular}

( Tclr = Tie-Tbe $)$, and the number of times that each driver checked left and right ( Nclr ) was determined from the footage of the driver. The above performance indicators were used to investigate the relationship between drivers' driving behaviors and the frequency of instructions by their instructors. The data on driving performance recorded by the drive recorder may have been imperfectly precise. Nevertheless, this method was deemed to be the best way to relatively analyze the behavior of the instructor and that of the driver. 


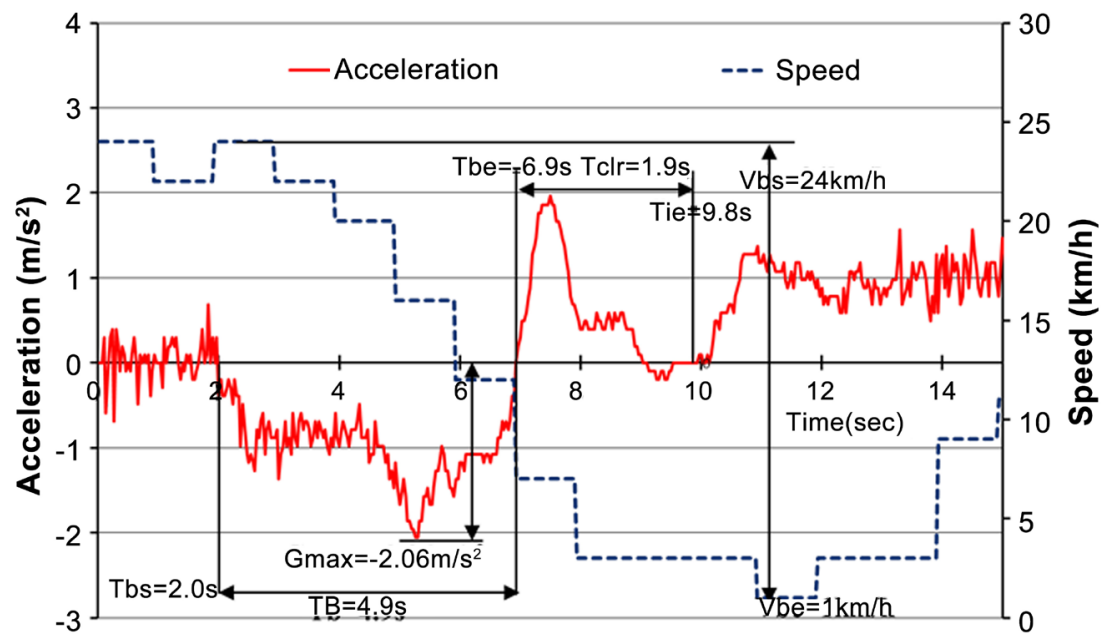

Figure 3. Example of the driving-recorder data analysis.

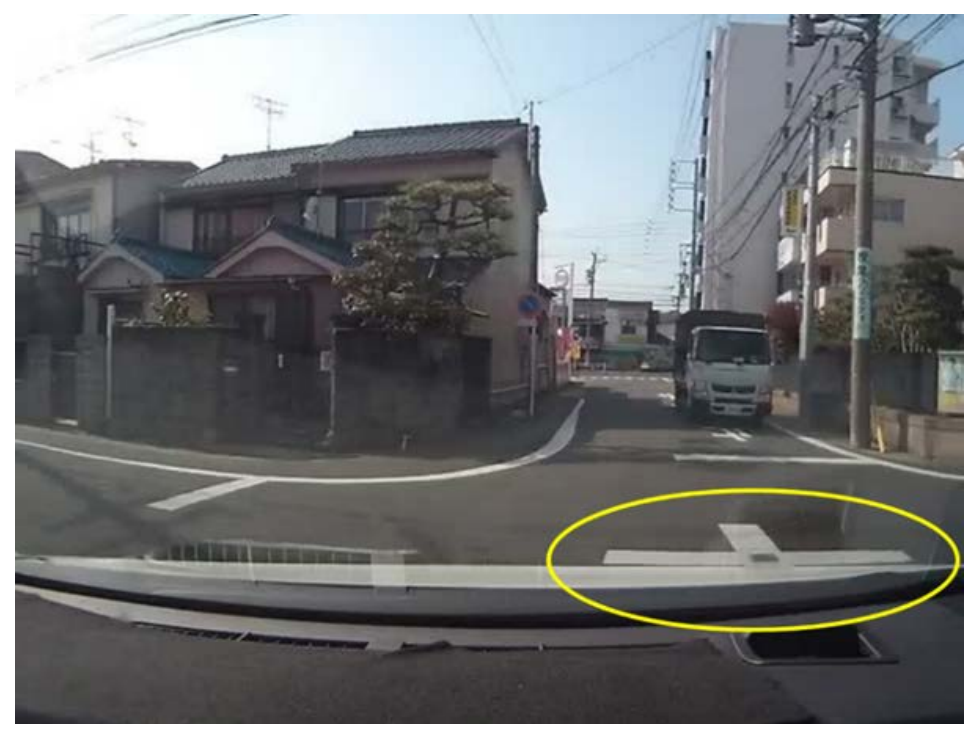

Figure 4. Intersection entering timing ( Tie ).

Table 3. Example of driving behavior calucration of the Figure 3 graph.

\begin{tabular}{ccc}
\hline Driving behavior & Symbol and Equation & Value \\
\hline Braking start speed & $V b s$ & $24 \mathrm{~km} / \mathrm{h}$ \\
Braking end speed & $V b e$ & $1 \mathrm{~km} / \mathrm{h}$ \\
Braking start time & $T b s$ & $2.0 \mathrm{sec}$ \\
Braking end time & $T b e$ & $6.9 \mathrm{sec}$ \\
Braking time & $T b=T b s-T b e$ & $4.9 \mathrm{sec}$ \\
Braking distance & $D b=T b \times(V b s-V b e) \div 3.6 \div 2$ & $16.3 \mathrm{~m}$ \\
Time margin of braking & $T b m=D b \div V b s \times 3.6$ & $2.45 \mathrm{sec}$ \\
Braking average deceleration & $G a v e=(V b s-V b e) \div T b$ & $2.06 \mathrm{~m} / \mathrm{sec}^{2}$ \\
Ratio of max and average deceleration & $R g=G$ max $\div$ Gave & 1.51 \\
Intersection entering time & $T i e$ & $9.8 \mathrm{sec}$ \\
Left and right checking time & $T c l r=T i e-T b e$ & $1.9 \mathrm{sec}$ \\
Number of left and right checks & Nclr & $4 \mathrm{times}$ \\
\hline
\end{tabular}




\section{Experiment Results}

\subsection{The Content of Instructions Given by Instructors}

Figure 5 shows the distribution of driving locations where instructors gave instructions (3117 instances) in all of the experimental drives by the 24 senior drivers. This study analyzed the instructions and driving behaviors for all instances at stop sign intersections (1004 instances), except in situations where things such as other vehicles had an interfering influence at the intersection.

Figure 6 shows the distribution of the intentions of instructions given at the stop sign intersections that were analyzed here. The driving instructions were carefully counted, and the drivers who received many driving instructions were considered to have poor driving performance. The relationship between instruction frequency on one side and cognitive attributes, physical attributes, and driving behaviors on the other was examined.

Figure 7 shows the distribution of the content of instructions that were given by the instructors, including advice on navigation, information, warnings, driving instructions, and driving interventions, at stop sign intersections. At stop sign intersections, the instructors frequently gave instructions to stop completely, stop before the stop line, and check left and right while moving forward slowly.

\subsection{The Relationship between Driving Behaviors and the Frequency of Driving Instructions}

Table 4 shows the driving instruction frequency and measured average data of driving behavior, cognitive function tests and driving aptitude tests of each subject. Based on this data, the correlation coefficient between each function was

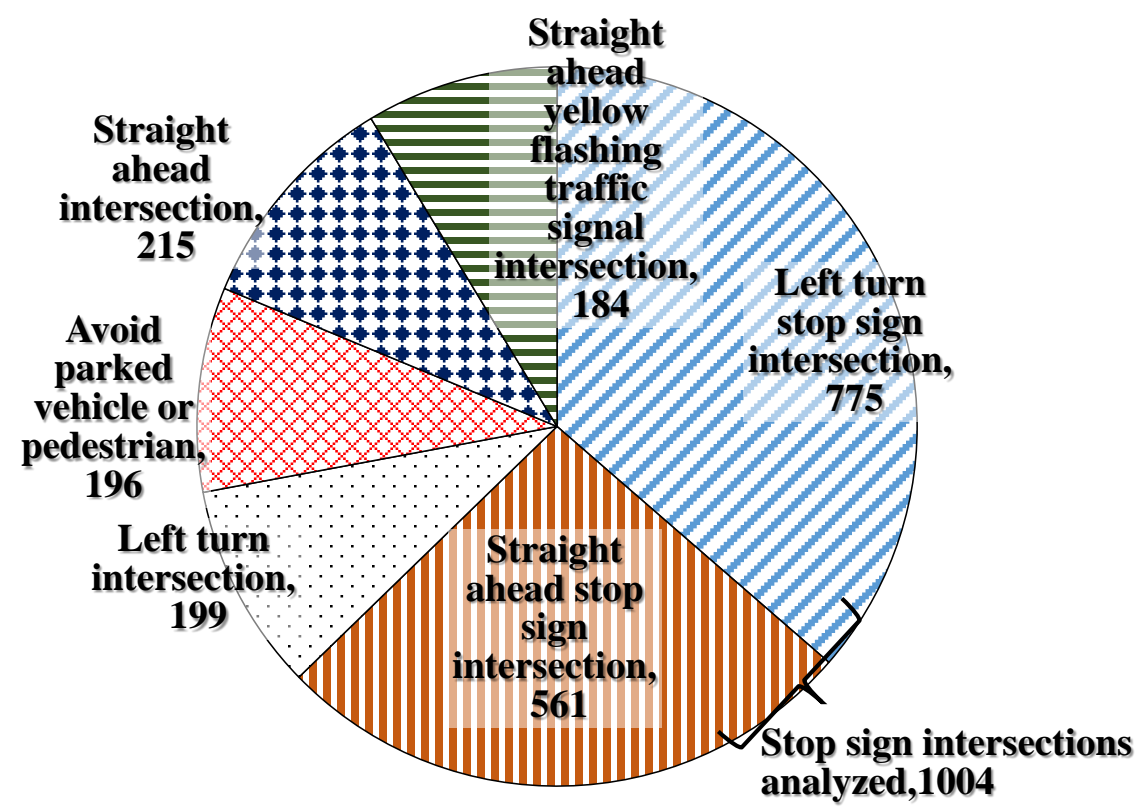

Figure 5. Distribution of driving situations where instruction was given (Total: 3117). 


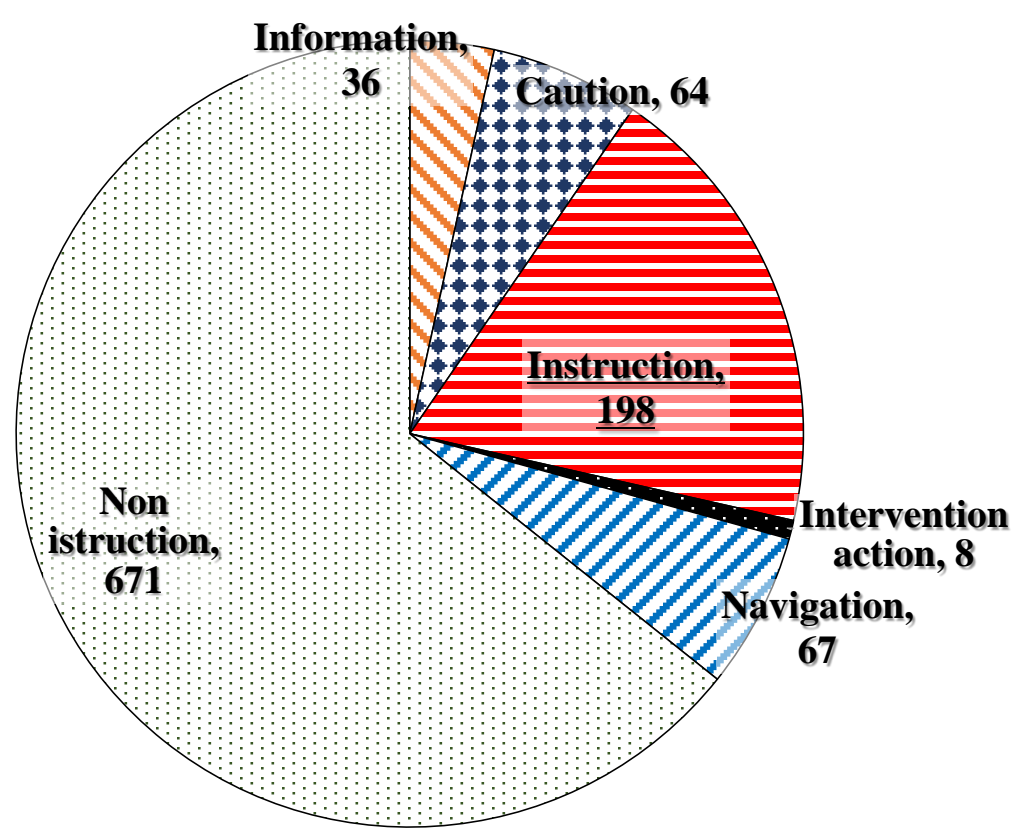

Figure 6. Distribution of the intention of instructions given at stop sign intersections.

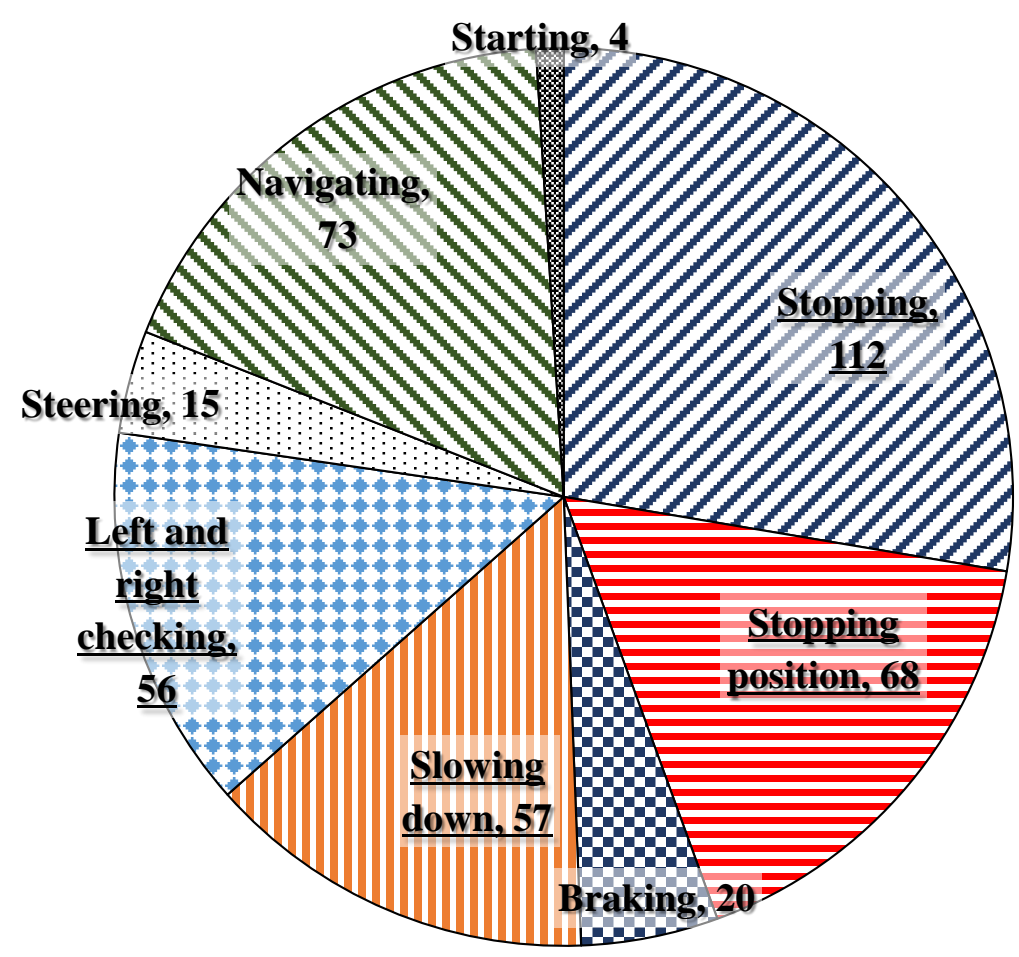

Figure 7. Distribution of the types of driving maneuvers that warranted instructions at stop sign intersections.

calculated using the Equation (1)-(5) and the relation of each function was studied. As there was a great deal of variation in human characteristics and human behaviors, it is very difficult to obtain a statistically significant confidence level for the correlation coefficient, requiring prohibitively numerous subjects and an 


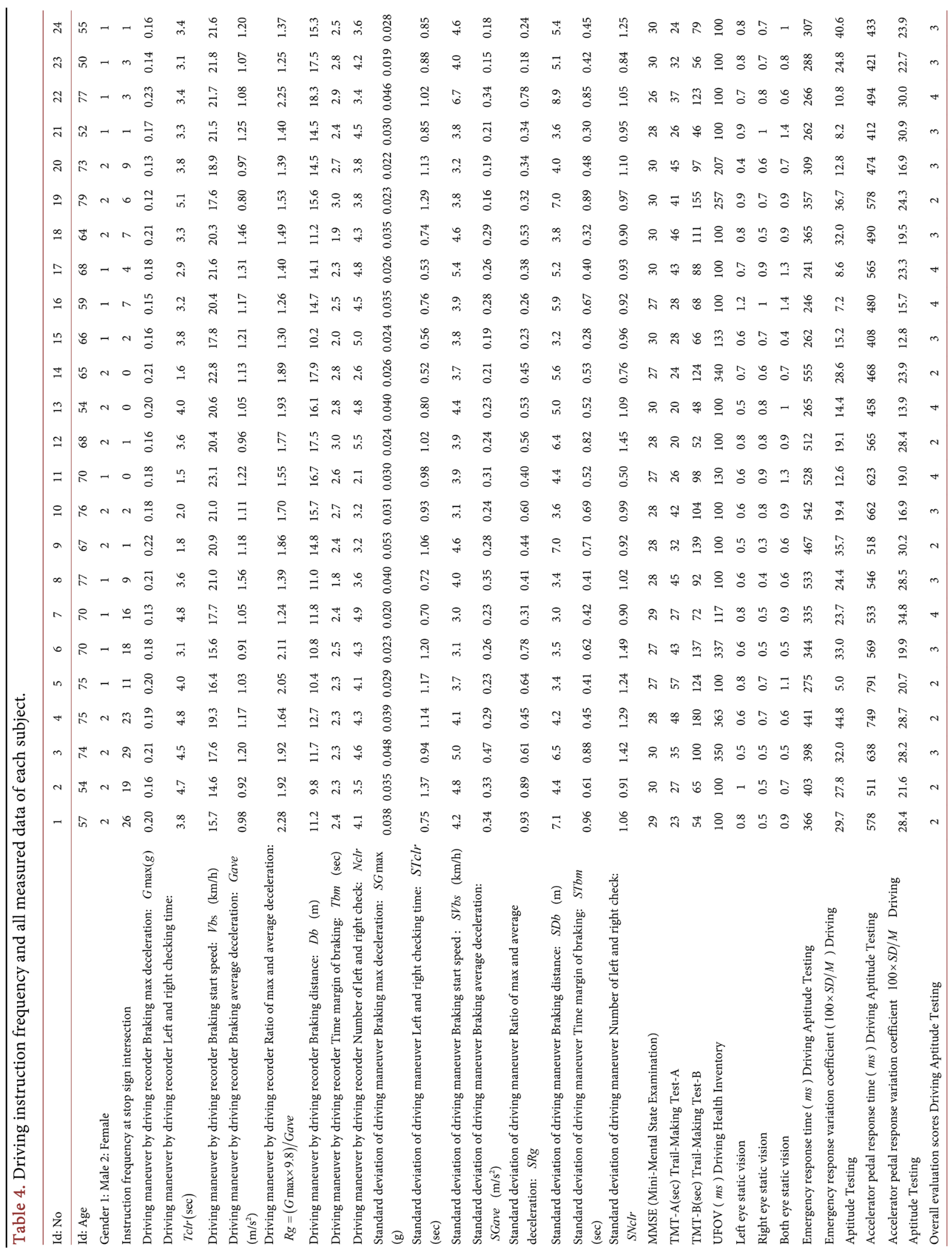


inordinate amount of data. Thus, correlation coefficients of 0.3 or more were interpreted as possibly indicating a correlation with an item, and the trends for each item were investigated.

$$
\begin{gathered}
x=\left\{x_{i}\right\} \\
\bar{x}=\frac{\sum_{i=1}^{n} x_{i}}{n} \\
y=\left\{y_{i}\right\} \\
y=\frac{\sum_{i=1}^{n} y_{i}}{n} \\
R=\frac{\sum_{i=1}^{n}\left(x_{i}-\bar{x}\right)\left(y_{i}-\bar{y}\right)}{\left(\sum_{i=1}^{n}\left(x_{i}-\bar{x}\right)^{2}\right)\left(\sum_{i=1}^{n}\left(y_{i}-\bar{y}\right)^{2}\right)^{1 / 2}}
\end{gathered}
$$

Table 5 shows the correlation coefficients of instruction frequency and the mean values and standard deviations of the following eight performance indicators for each of the drivers: braking start speed ( $\mathrm{Vbs}$ ); braking maximum deceleration ( $G \max$ ); braking average deceleration (Gave ); constant ratio of maximum deceleration to average deceleration as an indicator of the smoothness of braking ( $R g$ ); braking distance required for deceleration ( $D b$ ); time margin of braking ( $T m b$ ); time spent checking left and right, i.e., the interval between the

\begin{tabular}{|c|c|c|c|}
\hline $\begin{array}{l}\text { Driving behavior } \\
\text { (Mean value) }\end{array}$ & $\begin{array}{l}\text { Correlation with } \\
\text { instruction } \\
\text { frequency }\end{array}$ & $\begin{array}{l}\text { Driving behavior } \\
\text { (Standard } \\
\text { deviation) }\end{array}$ & $\begin{array}{l}\text { Correlation with } \\
\text { instruction } \\
\text { frequency }\end{array}$ \\
\hline $\begin{array}{l}\text { Braking start speed: Vbs } \\
(\mathrm{km} / \mathrm{h})\end{array}$ & -0.740 & $\begin{array}{c}\text { Vbs standard } \\
\text { deviation }(\mathrm{km} / \mathrm{h})\end{array}$ & -0.023 \\
\hline $\begin{array}{l}\text { Braking max deceleration: } \\
\qquad G \max \quad(\mathrm{g})\end{array}$ & -0.065 & $\begin{array}{c}G \text { max standard } \\
\text { deviation }(\mathrm{g})\end{array}$ & 0.219 \\
\hline $\begin{array}{l}\text { Braking average } \\
\text { deceleration: Gave }\left(\mathrm{m} / \mathrm{s}^{2}\right)\end{array}$ & -0.186 & $\begin{array}{l}\text { Gave standard } \\
\text { deviation }\left(\mathrm{m} / \mathrm{s}^{2}\right)\end{array}$ & 0.582 \\
\hline $\begin{array}{l}\text { Ratio of max and average } \\
\text { deceleration: } \\
R g=G \max / \text { Gave }\end{array}$ & 0.335 & $\begin{array}{l}R g \text { standard } \\
\text { deviation }\end{array}$ & 0.499 \\
\hline Braking distance: $D b \quad(\mathrm{~m})$ & -0.660 & $\begin{array}{l}\mathrm{Db} \text { standard } \\
\text { deviation }(\mathrm{m})\end{array}$ & -0.032 \\
\hline $\begin{array}{l}\text { Time margin of braking: } \\
\qquad \mathrm{Tbm} \quad(\mathrm{sec})\end{array}$ & -0.344 & $\begin{array}{l}\text { Tbm standard } \\
\text { deviation }(\mathrm{sec})\end{array}$ & 0.306 \\
\hline $\begin{array}{l}\text { Left and right checking time: } \\
\qquad \text { Tclr }(\mathrm{sec})\end{array}$ & 0.575 & $\begin{array}{l}\text { Tclr standard } \\
\text { deviation }(\mathrm{sec})\end{array}$ & 0.278 \\
\hline $\begin{array}{l}\text { Number of left and right } \\
\text { check: Nclr }\end{array}$ & 0.209 & $\begin{array}{l}\text { Nclr standard } \\
\text { deviation }\end{array}$ & 0.438 \\
\hline
\end{tabular}
completion of braking and the time of intersection entrance (Tclr ); and number of times each driver checked left and right ( Nclr ).

Table 5. Correlation coefficient of instruction frequency and driving behavior (mean values and standard deviations). 
From Table 5, it becomes apparent that the frequency of instructions at stop sign intersections correlates with driving characteristics. Drivers with a high frequency of instructions tended to have low speed at the start of braking (Vbs); spent a long time checking left and right ( Tclr ) (Figure 8), and checked left and right ( $N c l r$ ) many times. As shown in Figure 7, starting slowly from a complete stop at a stop sign intersection as advised by an instructor lowered the braking start speed and increased the time spent checking left and right. If it is assumed that the time of left and right checking was getting longer by frequent instructions to perform right and left checking while slowing down after stopping at the stop line, we can conclude that the association between a high frequency of instructions and left and right checking time is due to the drivers' responses to driving instructions.

In addition, drivers with a high frequency of instructions also exhibited a short braking distance ( $D b$ ) (Figure 9) and a short time margin of braking $(\mathrm{Tbm})$. They also exhibited increased ratios of maximum ( $G$ max ) and average braking deceleration (Gave). This indicated that their braking was not smooth. Drivers with a large standard deviation in all of their driving behaviors tended to get many instructions from their instructors. It is possible that the instructors felt that these types of driving behaviors indicated poor driving ability and accordingly gave more instructions to these drivers.

\subsection{Relationship of Driving Behavior, Cognition and Visual Function, Driving Instruction Frequency}

Table 6 shows the correlation coefficients of the frequency of driving instructions, driving characteristics, cognitive function scores, and eyesight scores. This

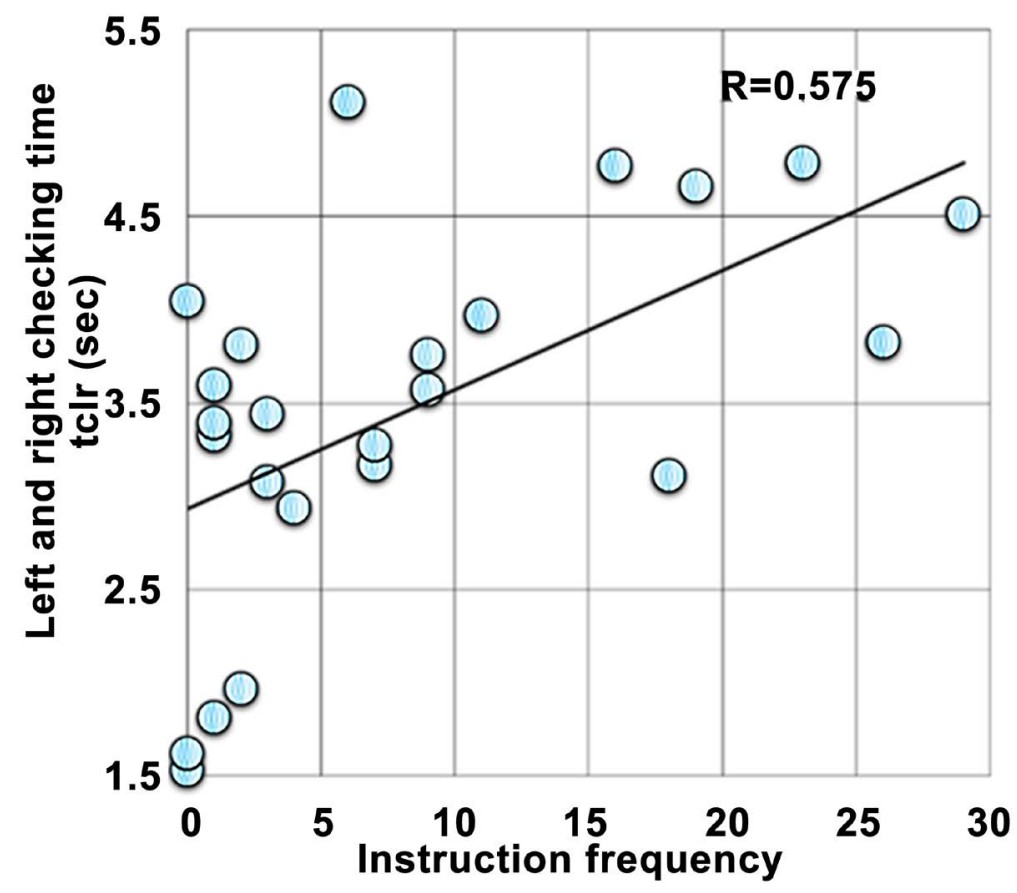

Figure 8. Correlation of instruction frequency and left and right checking time. 


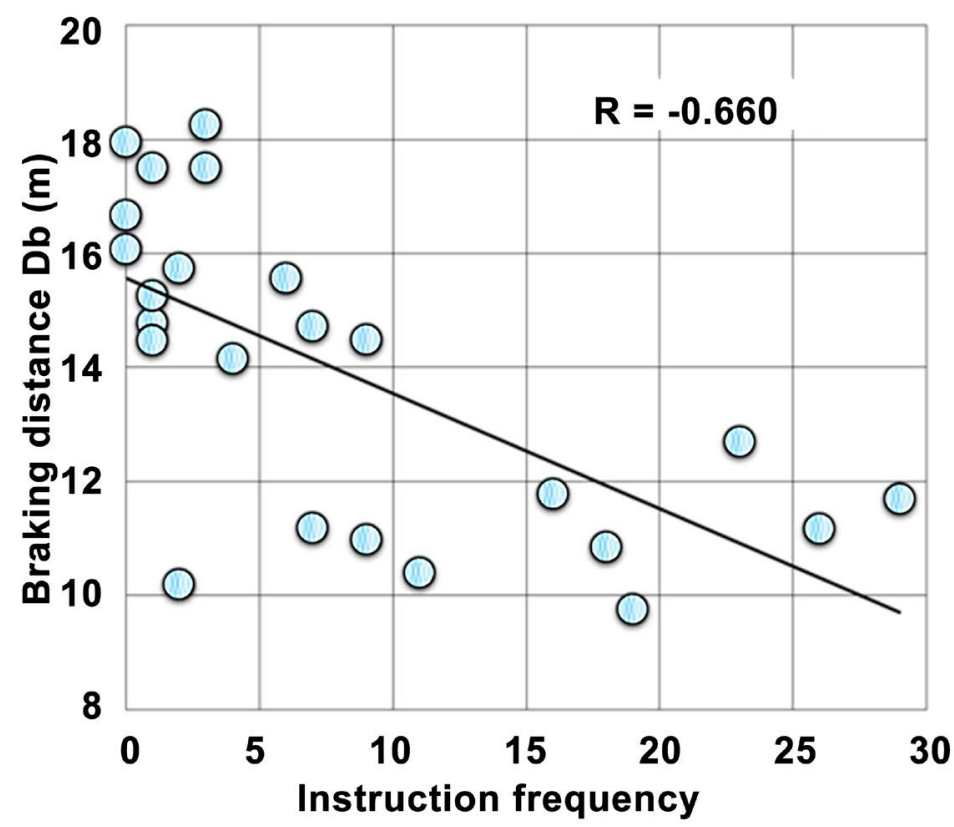

Figure 9. Correlation of instruction frequency and braking distance.

Table 6. Correlation coefficient of instruction frequency, driving behavior, cognition scores and eyesight scores.

\begin{tabular}{|c|c|c|c|c|c|c|c|}
\hline & MMSE & $\begin{array}{l}\text { TMT-A } \\
(\mathrm{sec})\end{array}$ & $\begin{array}{l}\text { TMT-B } \\
(\mathrm{sec})\end{array}$ & $\begin{array}{l}\text { UFOV } \\
(m s)\end{array}$ & $\begin{array}{l}\text { Left eye } \\
\text { static } \\
\text { vision }\end{array}$ & $\begin{array}{c}\text { Right eye } \\
\text { static } \\
\text { vision }\end{array}$ & $\begin{array}{l}\text { Both eye } \\
\text { static } \\
\text { vision }\end{array}$ \\
\hline Instruction frequency & 0.132 & 0.239 & 0.175 & 0.451 & -0.008 & -0.460 & -0.347 \\
\hline $\begin{array}{l}\text { Braking start speed: } \\
\qquad \operatorname{Vbs}(\mathrm{km} / \mathrm{h})\end{array}$ & -0.227 & -0.193 & -0.051 & -0.208 & -0.133 & 0.429 & 0.333 \\
\hline $\begin{array}{l}\text { Braking max deceleration: } \\
\qquad G \max (\mathrm{g})\end{array}$ & 0.398 & -0.144 & -0.255 & -0.048 & 0.362 & 0.240 & 0.195 \\
\hline $\begin{array}{l}\text { Braking average deceleration: } \\
\text { Gave }\left(\mathrm{m} / \mathrm{s}^{2}\right)\end{array}$ & -0.017 & 0.157 & -0.05 & -0.213 & -0.145 & -0.024 & 0.098 \\
\hline $\begin{array}{c}\text { Ratio of max and average } \\
\text { deceleration: } \\
R g=G \text { max/Gave }\end{array}$ & -0.373 & 0.016 & 0.241 & 0.202 & -0.185 & -0.259 & -0.298 \\
\hline Braking distance : $D b \quad(\mathrm{~m})$ & -0.249 & -0.348 & -0.023 & -0.064 & -0.032 & 0.489 & 0.263 \\
\hline $\begin{array}{l}\text { Time margin of } \\
\text { braking: } T b m \quad(\mathrm{sec})\end{array}$ & -0.169 & -0.303 & 0.027 & 0.105 & 0.056 & 0.373 & 0.127 \\
\hline $\begin{array}{l}\text { Left and right checking time: } \\
\qquad \text { Tclr } \quad(\mathrm{sec})\end{array}$ & 0.443 & 0.141 & -0.026 & 0.163 & 0.193 & -0.142 & -0.202 \\
\hline $\begin{array}{l}\text { Number of left and right } \\
\text { check: Nclr }\end{array}$ & 0.375 & -0.051 & -0.384 & -0.082 & 0.147 & 0.123 & 0.021 \\
\hline
\end{tabular}

table makes it apparent that drivers who scored poorly on the useful field of vision (UFOV) test had a higher frequency of instructions. The DHI UFOV task values $(\mathrm{ms})$ in Figure 10 represent the minimum value (the minimum value in this program was $100 \mathrm{~ms}$ ) of time required to correctly identify the position of a 
peripheral stimulus with more than $75 \%$ accuracy after correctly interpreting a stimulus in the center of the field of vision. In the measured value of UFOV in Figure 10, because the minimum display interval was $100 \mathrm{~ms}$, therefore it could not be evaluated when there was under $100 \mathrm{~ms}$ capability. The data of $100 \mathrm{~ms}$ were overlapped, and it was difficult to get the fitting straight line from the data point. Therefore, Figure 11 shows data excluding $100 \mathrm{~ms}$ data. Although the number of data points decreased, UFOV of the subjects with many instruction frequencies was getting worse. It was considered that the instructor increased adaptive instruction to subjects with low traffic environment recognition ability.

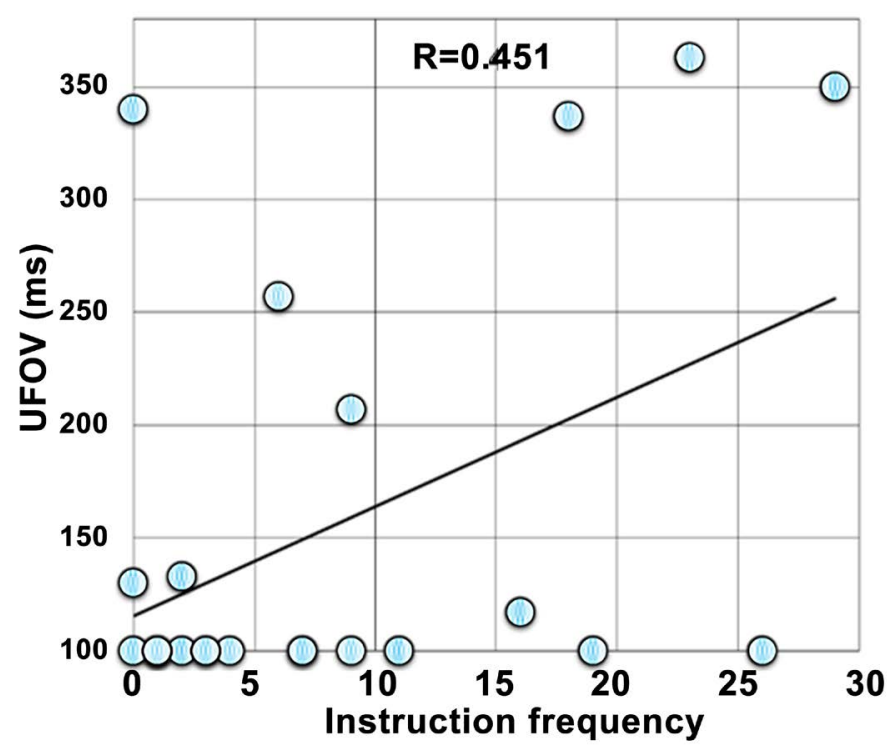

Figure 10. Correlation of instruction frequency and UFOV test score.

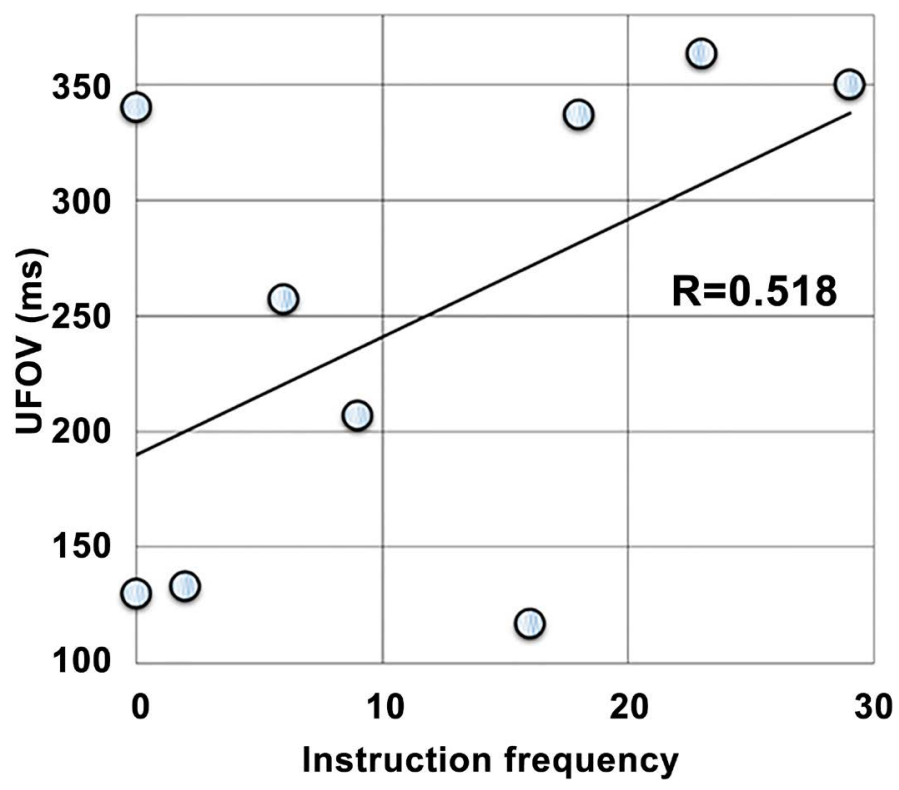

Figure 11. Correlation of instruction frequency and UFOV (Excluding data of $100 \mathrm{~ms}$ ) test score. 
Thus, it can be inferred that eyesight had an impact on driving performance as drivers with poor eyesight had a higher frequency of instruction. Based on this, it is presumed that instructors may have increased the frequency of their instructions in response to the drivers' seemingly diminished awareness of the surrounding environment and ability to process visual information. A correlation was also observed between scores on other cognitive tests and driving characteristics. Participants with low MMSE scores, for example, had short right and left checking durations (Figure 12) and a low frequency of left and right checks. They tended to be less safe drivers overall, with high fixed deceleration rate and poor steering. It was noted that drivers assessed by the TMT-A to have poor cognitive function also tended to have short braking distances and short time margins of braking. In other words, diminished cognitive function tended to be associated with unsafe driving behaviors and poor driving. In contrast, subjects with good eyesight had higher speeds at the start of braking as well as longer braking distances and longer time margins of braking. Thus, it is believed that perceptual faculties affect the ability to drive.

\subsection{The Relationships among Driving Aptitude Test Results, Frequency of Driving Instructions, and Driving Characteristics}

Table 7 shows the correlation coefficients of the frequency of driving instructions, driving characteristics, and driving aptitude test scores.

The relationship between the frequency of driving instructions, driving characteristics, cognitive scores and the items in the driving aptitude test that were focused on the response time of reflexes was investigated. Drivers who exhibited

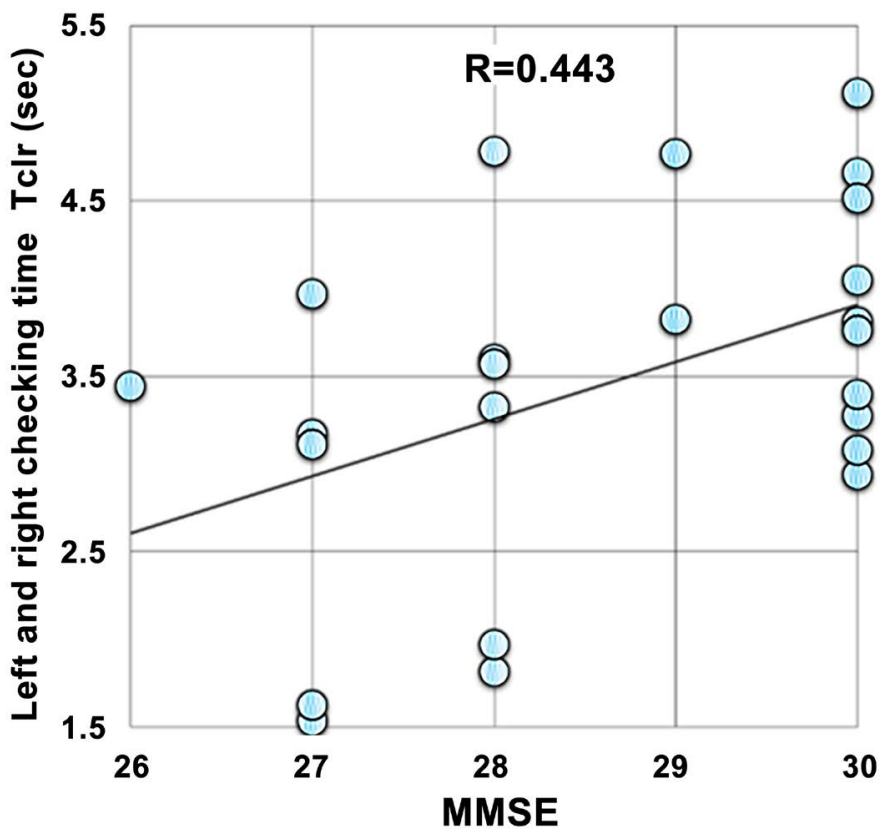

Figure 12. Correlation of MMSE (Mini-Mental State Examination) score and left and right checking time. 
Table 7. Correlation coefficient of instruction frequency, driving behavior and driving aptitude test scores.

\begin{tabular}{|c|c|c|c|c|c|}
\hline & $\begin{array}{l}\text { Emergency } \\
\text { response time } \\
\quad(m s)\end{array}$ & $\begin{array}{c}\text { Emergency } \\
\text { response variation } \\
\text { coefficient } \\
(100 \times S D / M)\end{array}$ & $\begin{array}{l}\text { Accelerator } \\
\text { pedal response } \\
\text { time }(m s)\end{array}$ & $\begin{array}{c}\text { Accelerator pedal } \\
\text { response variation } \\
\text { coefficient } \\
(100 \times S D / M)\end{array}$ & $\begin{array}{c}\text { Driving } \\
\text { aptitude test } \\
\text { overall } \\
\text { evaluation point }\end{array}$ \\
\hline Frequency of instruction & 0.003 & 0.392 & 0.467 & 0.287 & -0.255 \\
\hline $\begin{array}{l}\text { Braking start speed: Vbs } \\
(\mathrm{km} / \mathrm{h})\end{array}$ & 0.202 & -0.204 & -0.306 & 0.024 & 0.385 \\
\hline $\begin{array}{c}\text { Braking } \max \\
\text { deceleration: } G \max \quad(\mathrm{g})\end{array}$ & -0.288 & -0.046 & -0.251 & -0.173 & 0.070 \\
\hline $\begin{array}{l}\text { Braking average deceleration: } \\
\text { Gave }\left(\mathrm{m} / \mathrm{s}^{2}\right)\end{array}$ & 0.138 & -0.068 & -0.119 & 0.062 & 0.317 \\
\hline $\begin{array}{c}\text { Ratio of max and average } \\
\text { deceleration: } R g=G \max / \text { Gave }\end{array}$ & 0.165 & 0.104 & 0.369 & 0.132 & -0.339 \\
\hline Braking distance: $D b \quad(\mathrm{~m})$ & 0.143 & -0.164 & -0.259 & 0.032 & 0.199 \\
\hline $\begin{array}{l}\text { Time margin of } \\
\text { braking: } T b m \quad(\mathrm{sec})\end{array}$ & 0.052 & -0.072 & -0.089 & -0.014 & -0.025 \\
\hline $\begin{array}{l}\text { Left and right checking time: } \\
\qquad \text { Tclr (sec) }\end{array}$ & -0.389 & 0.197 & 0.147 & 0.193 & -0.146 \\
\hline $\begin{array}{l}\text { Number of left and right check: } \\
\qquad N c l r\end{array}$ & 0.519 & -0.143 & -0.104 & 0.035 & 0.108 \\
\hline
\end{tabular}

delayed response in pressing the accelerator (Figure 13) and wide scattering in their emergency response times tended to have a high frequency of instructions by their instructor. Moreover, drivers who exhibited delayed emergency responses had short right and left check times and low numbers of left and right checks (Figure 14). Conversely, drivers whose overall scores were good had high starting brake speeds, large average deceleration values, and small fixed deceleration ratios (Figure 15). Therefore, drivers who have a strong aptitude for driving drive at slightly faster speeds and apply constant deceleration when braking. They also tend to be skillful in their maneuvers and receive just a few instructions from their instructors. Accordingly, it is believed that a high driving aptitude as assessed by the driving aptitude test corresponds to our indicators of driving characteristics.

\section{Conclusions}

The subjects (senior drivers) drove on a predetermined course and were accompanied by driving instructors from a driving school who sat in the passenger seat and gave them driving instructions. The relationship between their driving ability on one side and their cognitive and physical attributes on the other was analyzed on the basis of their driving behaviors at stop signs and the frequency with which driving instructions were given at stop sign intersections. The results revealed the following trends.

The instructions that were most frequently given by the instructors at stop sign intersections were reminders to completely stop before the stop line of the intersection and to check left and right while starting very slowly from the com- 
plete stop. Drivers who received many instructions had slow driving speeds and took a long time to enter each intersection because they spent more time checking left and right before proceeding. They also checked left and right many times, presumably in response to the instructions they were given during the experimental drive.

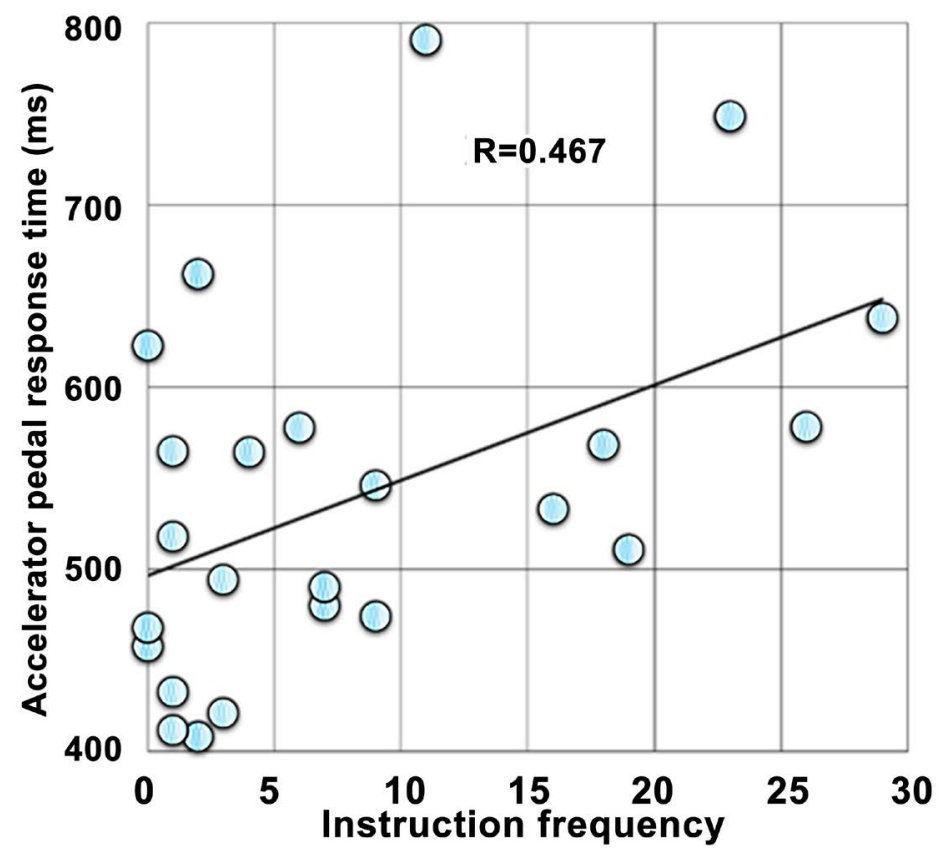

Figure 13. Correlation of instruction frequency and accelerator pedal response time in driving aptitude tests.

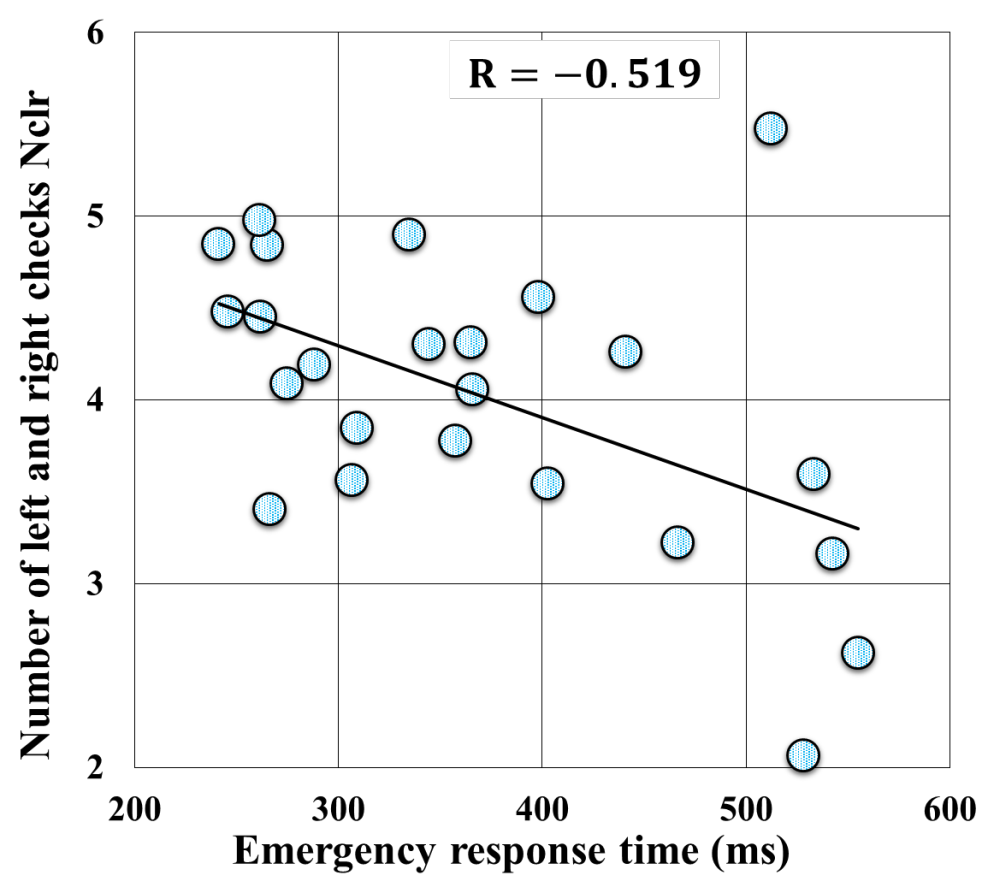

Figure 14. Correlation of emergency response time and number of left and right checks. 


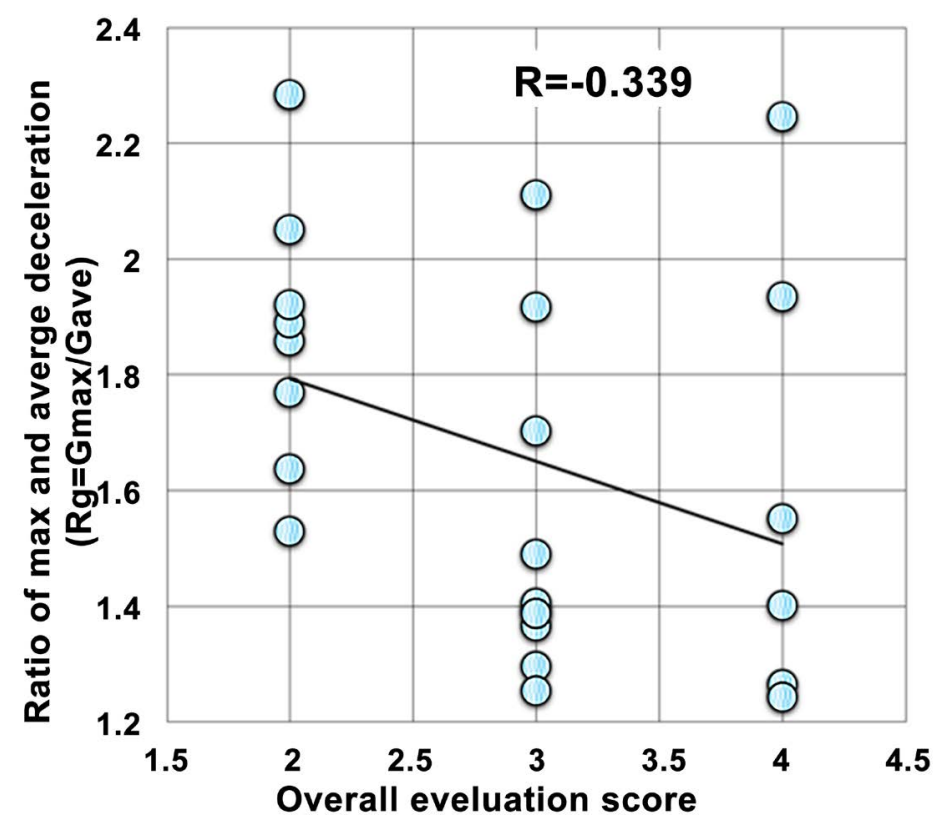

Figure 15. Correlation of overall evaluation score and ratio of max and average deceleration.

The following trends were revealed regarding the relationships among the cognitive and physical attributes of senior drivers, frequency of instruction, and driving behaviors: drivers who received many instructions tended to respond poorly to peripheral stimulation as inferred from the results of their UFOV test results; drivers with diminished cognitive function (low MMSE scores and high TMT-A and TMT-B scores) tended to check left and right less and had short left and right check times. These drivers exhibited delays at the start of braking; could not brake smoothly, i.e., with constant deceleration; and showed wide variations in their driving behaviors.

The above results indicate that driving school instructors judge their students' abilities and adjust their driving instructions on the basis of that judgment. It is believed that the instructions given during the experimental drives in this study increased safe driving behaviors such as complete stops and left and right checks.

From the relationship between the frequency of instructions and the driving behaviors of elderly subjects as captured by the driving recorder, it appears that a system of training that helped senior drivers increase the amount of time spent checking left and right and the number of left and right checks at stop sign intersections would be effective for promoting safe driving among the elderly. These items when considered together could serve as a good performance indicator for the ability to drive safely. In addition, other good performance indicators of skillful driving could be the constant deceleration ratio of the average deceleration and maximum deceleration of a single application of the brake, the braking distance, and the time margin of braking.

In the future, driving characteristics should be assessed using these perfor- 
mance indicators and efforts should be made to develop a driving instruction system that can be adapted to the individual depending on driving ability.

\section{Acknowledgements}

This research is supported by the Center of Innovation Program (COI) from Japan Science and Technology Agency, JST. This study was made possible by the cooperation of the instructors at the Chubu Nippon Driver School, whose instructions were recorded and analyzed herein. We were fortunate to be able to use a database that had been compiled by members of the COI groups. We would like to express our deepest gratitude to all who contributed to this study.

\section{References}

[1] National Police Agency (2015) Statistical Traffic Accident Data. http://www.npa.go.jp/toukei/koutuu48/toukeie.htm

[2] Aoki, H., Kanamori, H., Yamagishi, M., Tanaka, T., Takahashi, I., Yonekawa, T., Kawano, N., Ito, Y., Iwamoto, K., Ozaki, N., Terasaki, H., Obinata, G., Akamatsu, M., Sato, T., Oguri, K., Kawanaka, H. and Nakagawa, T. (2015) Study on Driver Characteristics for Delaying Driving Cessation (1) Database Construction of Older Drivers' Human, Aging, Driving Characteristics (in Japanese with English summary). JSAE 20155208, 2015 JSAE Annual Spring Congress Proceedings, Yokohama, 20-22 May 2015, 1091-1094.

[3] Yamagishi, M., Aoki, H., Tanaka, T., Takahashi, I., Kawano, N., Sato, T., Aakamatsu, M. and Kanamori, H. (2015) Study on Driver Characteristics for Delaying Driving Cessation (2) Correlation Analyses between Fundamental Characteristics of Older Drivers and Their Driving Behavior (in Japanese with English summary). JSAE 20155209, 2015 JSAE Annual Spring Congress Proceedings, Yokohama, 20-22 May 2015, 1095-1100.

[4] Institute for Traffic Accident Research and Data Analysis (ITARDA) (2007) Accidents Involving Elderly Drivers. 2007-06, ITARDA Information, No. 68. http://www.itarda.or.jp/itardainfomation/info68.pdf

[5] Yonekawa, T., Murano, T. and Iwazaki, K. (2014) Analysis of Accident When Turning Right at Intersection Using Driving Simulator. International Journal of Vehicle Safety, 7, 17-36. https://doi.org/10.1504/IJVS.2014.058239

[6] Yonekawa, T., Sasaki, K. and Iwazaki, K. (2014) Driving Behavior Analysis of Elderly Drivers Passing through Stop Sign Intersection Using Driving Simulator. International Journal of Automotive Engineering, 5, 137-144.

[7] Y. Yoshihara, E. Takeuchi, Y. Ninomiya (2015)Acquisition and Analysis of Driving Data of Expert and Elderlies in Residential Area toward Developing a Referential Driving Behavior Model Adapted for Elderlies (in Japanese with English summary). JSAE 20155241, 2015 JSAE Annual Spring Congress Proceedings, Yokohama, 20-22 May 2015, 1246-1251.

[8] Yonekawa, T., Tanaka, T., Aoki, H., Yamagishi, M., Yoshihara, Y., Takeuchi, E., Takahashi, I., Ninomiya, Y. and Kanamori, H. (2015)Analysis of Instructor's Teaching of Senior Drivers' Safety Urban Driving Behavior (in Japanese with English summary). JSAE 20156054, 2015 JSAE Annual Autumn Congress Proceedings, Kitakyushu, 14-16 October 2015, 276-281. 
Submit or recommend next manuscript to SCIRP and we will provide best service for you:

Accepting pre-submission inquiries through Email, Facebook, LinkedIn, Twitter, etc. A wide selection of journals (inclusive of 9 subjects, more than 200 journals)

Providing 24-hour high-quality service

User-friendly online submission system

Fair and swift peer-review system

Efficient typesetting and proofreading procedure

Display of the result of downloads and visits, as well as the number of cited articles Maximum dissemination of your research work

Submit your manuscript at: http://papersubmission.scirp.org/

Or contact jtts@scirp.org 